Karol Petryszak

Uniwersytet Papieski Jana Pawła II w Krakowie

\title{
KRYTYKA I PROPOZYCJE ROZSZERZENIA ONTYCZNYCH PODSTAW ODPOWIEDZIALNOŚCI ROMANA INGARDENA
}

W 1970 roku Roman Ingarden wydał pracę Über die Verantwortung. Ihre ontischen Fundamente, która w języku polskim ukazała się pod tytułem: O odpowiedzialności i jej podstawach ontycznych w przekładzie Adama Węgrzeckiego. Polski fenomenolog podjął w niej próbę ustalenia podstaw odpowiedzialności. Trop ten stanowi płodny punkt wyjścia do analizy i krytyki etycznej. Niemniej wydaje się, że Ingarden - mimo zamysłu oddania idei odpowiedzialności w jej najbardziej podstawowym stanie - posłużył się w analizie założeniami, które zdaniem autora niniejszego artykułu są nie tylko zbędne, ale również błędne, z uwagi na niemożność wykazania ich koniecznego związku z odpowiedzialnością. Nie umniejsza to jednak pozostałych walorów refleksji polskiego fenomenologa, które na płaszczyznach pozaontycznych nie budzą w zasadzie zastrzeżeń. Mam tu na myśli odpowiedzialność prawną, moralną, świadome podejmowanie odpowiedzialności czy odpowiedzialne działanie; te aspekty chciałbym jednak pominąć. Skupię się natomiast na próbie wykazania, że odpowiedzialność obejmuje szerszy zbiór osób, niż przewidywał Ingarden, a także że nie łączy się w sposób konieczny z wartościami, jak też nie jest stopniowalna w jej wymiarze ontologicznym.

Dla porządku należy przypomnieć, jakie sytuacje odpowiedzialności zostały wyróżnione przez autora Książeczki o człowieku: „1. Ktoś ponosi odpowiedzialność za coś (...). 2. Ktoś podejmuje odpowiedzialność za coś. 3. Ktoś jest za coś pociągany do odpowiedzialności. 4. Ktoś działa 
odpowiedzialnie"1. Omówieniu każdego z punktów Ingarden poświęcił osobną analizę. Warto wskazać również na paragraf IV, zatytułowany: Wartość jako ontyczny fundament odpowiedzialności². Zamyka on niejako dyskusję na powrót - o czym była mowa w poprzednim akapicie - o obrębie odpowiedzialności moralnej. Ingarden niewątpliwie przyjął koncepcję przedstawioną w Ethik Nicolaia Hartmanna. Zbieżność założeń widać zwłaszcza pomiędzy wspomnianym paragrafem VI polskiego fenomenologa a paragrafem, który Hartmann zatytułował: Philosophischer Antropomorphismus und Primat der axioloischen Determination $^{3}$. Do tego fragmentu Ingarden nie odwołał się bezpośrednio, ale w przypisach wspominał o pracy niemieckiego filozofa, co dodatkowo wzmacnia postawioną powyżej tezę o zbieżności założeń.

Dla zachowania jak największej klarowności dalsza część tekstu została podzielona na cztery paragrafy. W pierwszym przedstawiam postulowane przez Ingardena założenia w kwestii samej odpowiedzialności na jej płaszczyźnie ontycznej. Następnie prezentuję poczynione przez niego założenia dotyczące podmiotu odpowiedzialnego. Kolejno staram się wykazać aksjologiczny charakter tez autora $O$ dziele literackim. Ostatni paragraf zawiera zaś krytykę omawianego punktu koncepcji Ingardena i próbę jej uzupełnienia.

\section{PRZEDSTAWIENIE POSTULOWANEGO ZAMIARU INGARDENA}

Autor O dziele literackim zaczyna refleksję od konstatacji, że odpowiedzialność do czasów mu współczesnych nie została dostatecznie przebadana, a także że jej dalsze związki nie zostały wykazane w sposób zadowalający ${ }^{4}$. W pierwszych zdaniach artykułu znajduje się również

1 R Ingarden, O odpowiedzialności i jej podstawach ontycznych, tłum. A. Węgrzecki, w: R. Ingarden, Książeczka o człowieku, Kraków 2003, s. 73-74.

2 Zob. R. Ingarden, O odpowiedzialności..., s. 97 n.

3 Zob. N. Hartmann, Ethik, Berlin 1962, s. 202-203.

4 Zob. R. Ingarden, O odpowiedzialności..., s. 73. 
próba wprowadzenia wyraźnego rozdziału pomiędzy etyką, która dotychczas, tj. do lat siedemdziesiątych XX wieku, miała niejako monopol na zajmowanie się odpowiedzialnością, a ontologią i metafizyką ${ }^{5}$. Aby nie wprowadzać niepotrzebnych podziałów, Ingarden zauważył, że odpowiedzialność jest oczywiście przynależna refleksji etycznej, ale "odpowiedzialność moralna stanowi tylko pewien szczególny wypadek" Należy więc rozszerzyć pole refleksji i wprowadzić odpowiedzialność na płaszczyznę chociażby metafizyki ${ }^{7}$. To rozszerzenie pozwala na wyciągnięcie wniosku, że odpowiedzialność moralna, tj. taka, która odnosi się do relacji podmiotu i wartości, stanowi tylko jeden z wypadków odpowiedzialności jako takiej. Wynika z tego, że nie może ona być podstawą dowolnych sądów o odpowiedzialności. Zatem odpowiedzialność może dotyczyć takich elementów, które będą istniały poza wartościami. Można oczywiście założyć, że takie elementy rzeczywistości, które w żaden sposób nie byłyby związane ze światem wartości - jakkolwiek pojmowanych - nie istnieją, niemniej nie zgadza się to z założeniami samego Ingardena, że znaczna część zachowań czy rzeczy jest neutralna aksjologicznie ${ }^{8}$.

Ubiegając nieco kolejny paragraf - konieczne jest wskazanie, że odpowiedzialność miała dla polskiego fenomenologa charakter relacyjny, co udowadniał przez analizę zwrotu „ktoś ponosi odpowiedzialność

${ }^{5}$ Ingarden nie precyzował, czy będzie analizował odpowiedzialność z punktu widzenia metafizyki, czy ontologii - w rozumieniu podziału zaproponowanego przez niego pomiędzy obiema płaszczyznami (por. R. Ingarden, Spór o istnienie świata, t. I, tłum. D. Gierulanka, Warszawa 1987, s. 45-63). Mimo że z tytułu wynikałoby, że autor będzie zajmował się ontologią, to dalsze jego rozważania zdają się wskazywać, że łączył obie płaszczyzny i z badania zaistnienia odpowiedzialności w konkretnych przypadkach starał się wyprowadzać wnioski właściwe płaszczyźnie ontologicznej - co nie stoi w sprzeczności z wnioskami i metodą zaproponowaną przez Ingardena w Sporze o istnienie świata; niemniej badanie podstaw ontycznych nie wymusza przechodzenia na płaszczyznę metafizyczną.

${ }^{6}$ R. Ingarden, O odpowiedzialności..., s. 73.

7 Zob. R. Ingarden, O odpowiedzialności..., s. 73.

8 Zob. R. Ingarden, O odpowiedzialności..., s. 8o. 
za coś”, co pozwala - jak wynika z dalszej analizy - rozumieć odpowiedzialność w jej podstawowym wymiarze jako: relację pomiędzy podmiotem i jego działaniem, a także skutkami tego działania9. Zarówno odnośnie do poprzedniego zdania, jak i do krytycznej (ostatniej) części niniejszego artykułu może pojawić się zarzut, że odpowiedzialność za coś - w rozumieniu Ingardena - jak też zaproponowana przeze mnie „odpowiedzialność fundamentalna" są bliskoznaczne lub tożsame ze sprawstwem. Jest to zarzut nieuzasadniony, gdyż semantyka sprawstwa jest konstytuowana przez aktualny system prawny, który nie może być brany pod uwagę podczas analizy ontologicznej z uwagi na jego zmienność, konwencjonalność i niekonieczność. Ponadto warto zaznaczyć, że sprawstwo odwołuje się do kategorii czynów przestępczych, co byłoby rażącym zawężeniem rozumienia ontycznych podstaw odpowiedzialności.

\section{ZAŁOŻENIA INGARDENA O PODMIOCIE „ZA COŚ ODPOWIEDZIALNYM"}

Wyrażone wprost założenia autora Książeczki o człowieku brzmią następująco: „sprawcą, który ma ponosić odpowiedzialność, może być jedynie jakiś człowiek"10. Ingarden zaznaczył jednak, że tylko niektórzy ludzie, tylko w określonych sytuacjach mogą być odpowiedzialni za swoje czyny. Oczywiście można się zgodzić z przykładem podanym dla zobrazowania wyjątkowości człowieka, tj. kot przebiegający przez ulicę nie jest odpowiedzialny za wypadek, który spowodował - za wypadek odpowiedzialność ponosi kierowca ${ }^{11}$. Dalej jednak autor doprecyzował, że jedynie człowiek, „który w momencie działania jest jego świadom i posiada wszystkie «normalne» zdolności niezbędne do opanowania sytuacji i który wreszcie coś czyni albo w momencie, w którym miał uczynić coś określonego, zaniechał uczynienia tego", może być odpowiedzialny

9 Zob. R. Ingarden, O odpowiedzialności..., s. 77-78.

${ }^{10}$ R. Ingarden, O odpowiedzialności..., s. 77.

11 Zob. R. Ingarden, O odpowiedzialności..., s. 77, przypis 2. 
za swój czyn ${ }^{12}$. Konieczne jest również nadmienienie, że tego rodzaju zdolności prezentuje według Ingardena tylko osoba, tj. taki byt, dla którego jest „konstytutywne to, że jest on punktem źródłowym możliwych decyzji opartych na zrozumieniu sytuacji wziętej w aspekcie wartości”; osoba jest zarazem „zdolna realizować to, co sama postanowiła” ${ }^{13}$. Nie należy formułować na podstawie przytoczonej wypowiedzi szerszej teorii osoby autora Sporu o istnienie świata ${ }^{14}$. Chodzi jedynie o wskazanie na rozumny, wolitywny i aksjologiczny charakter. W świetle tego oraz dalszych rozważań czyn, za który osoba jest odpowiedzialna, nie jest ani pasywnym brakiem reakcji na stany od danej osoby niezależne, ani odruchem, którego natury nie można rozpoznać w odpowiednim momencie $\mathrm{z}$ uwagi na jego automatyzm i bezrefleksyjność ${ }^{15}$.

Powstaje zatem pytanie, na które uwagę zwrócił również Ingarden: „jak należy określić najniższy stopień uświadomienia, przy którym znajdujące się w trakcie spełnienia działanie leży jeszcze w zasięgu odpowiedzialności sprawcy" ? ${ }^{16}$ Niestety, autor nie podał jednoznacznej odpowiedzi. Wydaje się jednak, co można wywnioskować z przywołanych już założeń oraz kontekstu, że osoba jest odpowiedzialna za działanie wówczas, gdy jest świadoma tego, co robi, rozpoznaje wartości towarzyszące jej działaniom oraz jest wolna w rozumieniu wolności jako „układu względnie izolowanego"17. Niemniej jest to kwestia trudna do rozpoznania i jasnego podziału na kategorie ${ }^{18}$.

W świetle omawianej koncepcji podmiot jest również odpowiedzialny za wynik swojego czynu. Ingarden podał za przykład pozbawienie kogoś życia w samoobronie oraz budowę mostu ${ }^{19}$. Oba działania niosą

${ }^{12}$ Zob. R. Ingarden, O odpowiedzialności..., s. 77, przypis 2.

${ }^{13}$ R. Ingarden, O odpowiedzialności..., s. 77-78.

${ }^{14}$ Sam nadmienił, że jest to sprawa trudna i nie ma zgody co do tego, kim jest osoba. Zob. R. Ingarden, O odpowiedzialności..., s. 77.

${ }_{15}$ Zob. R. Ingarden, O odpowiedzialności..., s. 78.

${ }^{16}$ R. Ingarden, O odpowiedzialności..., s. 79.

${ }_{17}$ R. Ingarden, O odpowiedzialności..., s. 122-148.

18 Zob. R. Ingarden, O odpowiedzialności..., s. 79.

19 Zob. R. Ingarden, O odpowiedzialności..., s. 8o-81. 
ze sobą odpowiedni bagaż wartości pozytywnych i negatywnych. Stąd też można je rozpatrywać w kontekście odpowiedzialności, ponieważ: „kiedy są one [działania/czyny - K. P.] absolutnie neutralne co do wartości (...), sprawca jest wprawdzie zawsze ich twórcą, ale samo to nie pozwala, by się wyłoniło pytanie o jego odpowiedzialność" ${ }^{20}$. Wynikają z tego dwa wnioski. Przede wszystkim - istnieją byty neutralne aksjologicznie. Po wtóre o odpowiedzialności można mówić tylko wówczas, gdy dotyka ona sfery wartości. Wnioski te zostały rozwinięte w kolejnym paragrafie.

Aby dane działanie mogło być rozpatrywane w kategoriach odpowiedzialności, musi być ono wolne i wypływać z ,ja osobowego" ${ }^{21}$, które można scharakteryzować jako tę właściwość wewnętrzną bytu osobowego, „w której decyzja woli i podjęte przez osobowe «ja» działanie dokonuje się w ścisłym sensie jako «własne» działanie (czyn) danej osoby" ${ }^{22}$. Jest to opis sytuacji idealnej. Człowiek jednak jest „układem względnie izolowanym", co oznacza, że absolutnie wolne ja osobowe wchodzi w relacje z determinującym światem zewnętrznym. Na podstawie każdorazowego wyniku tego spotkania negocjuje się układ względnie wolny i jednocześnie względnie determinowany. Ingarden dopuszczał nawet sytuację, w której człowiek nie byłby w stanie podjąć żadnego wła s n e go działania. Zdaniem autora $O$ dziele literackim jest to granica absolutnego braku odpowiedzialności za wykonywane czyny ${ }^{23}$. Są to oczywiście przypadki graniczne, a pomiędzy nimi rozciąga się szeroki wachlarz stanów pośrednich, które w zależności od zbliżania się ku jednemu ze stanów granicznych nakładają na działającego większą lub mniejszą odpowiedzialność. Wynika z tego, że odpowiedzialność jest stopniowalna, co nie znaczy, że jest relatywna, chociaż pozornie może się tak wydawać ${ }^{24}$.

\footnotetext{
${ }^{20}$ R. Ingarden, O odpowiedzialności..., s. 81.

21 Zob. R. Ingarden, O odpowiedzialności..., s. 85-86.

${ }^{22}$ R. Ingarden, O odpowiedzialności..., s. 85.

${ }^{23}$ Zob. R. Ingarden, O odpowiedzialności..., s. 86, 92.

${ }^{24}$ Zob. R. Ingarden, O odpowiedzialności..., s. 74, 86.
} 


\section{AKSJOLOGICZNY CHARAKTER ZAŁOŻEŃ INGARDENA}

Jak wskazałem we wstępie, Ingarden dowodził, że wartość jest ontycznym fundamentem odpowiedzialności ${ }^{25}$. Taka konstatacja lokuje odpowiedzialność na powrót w polu odpowiedzialności moralnej. Zakłada to również obiektywne istnienie wartości, których rozpoznanie stanowi jeden z koniecznych elementów mówienia o odpowiedzialności. Wskazuje na to także - wywiedzione z faktu, że „odpowiedzialność ciąży na sprawcy" ${ }^{26}$ - założenie Ingardena, że osoba działająca może się „«odciążyć» od swego brzemienia przy pomocy jakiegoś nowego, odpowiednio ukształtowanego (...) czynu, ale nikt inny"27. Dla utrzymania w mocy powyższej tezy presupozycja jest następująca: istnieje mierzalny, obiektywnie lub przez porównanie, „ciężar gatunkowy” wartości ${ }^{28}$. To z kolei pozwala domniemywać, że wartości posiadają strukturę hierarchiczną i stałą - przynajmniej względnie ${ }^{29}$. Potwierdza to założenie Ingardena:

\section{(...) ta zrazu mało przejrzysta zależność wielkości i rodzaju odpowie- dzialności od wchodzących w rachubę wartości możliwego wyniku umacnia moje przekonanie, że bez wszelkiej wartości wyniku, a także samego działania, nie mogłoby dojść do żadnej odpowiedzialności ${ }^{30}$.}

Warto zwrócić uwagę na użycie negatywnie nacechowanych słów. Wyrażenie „odpowiedzialność ciążąca na sprawcy” konotuje obrazy

${ }^{25}$ Patrz początek niniejszego artykułu. Por. też R. Ingarden, O odpowiedzialności..., s. 81.

${ }^{26}$ R. Ingarden, O odpowiedzialności..., s. 75.

${ }^{27}$ R. Ingarden, O odpowiedzialności..., s. 75. Pomijam teologiczne konsekwencje tego twierdzenia.

${ }^{28}$ Mimo że określenie „ciężar gatunkowy” nie wydaje się najtrafniejsze, to zastępuje ono wieloznaczne w języku polskim słowo „wartość”.

${ }^{29}$ Być może również to jest pokłosiem wpływu koncepcji etycznych Hartmanna. Por. R. Ingarden, O odpowiedzialności..., s. 83.

${ }^{30}$ R. Ingarden, O odpowiedzialności..., s. 82. 
procesu karnego, występku, konfliktu z prawem, konieczność odpokutowania winy, poniesienia kary itd.

Ważne wydaje się rozróżnienie na odpowiedzialność i winę, które poczynił również Ingarden, jednak zespalając je ze sobą, w tym sensie, że pociągnięcie do odpowiedzialności jest logiczną konsekwencją „bycia za coś odpowiedzialnym"31. Wydaje się jednak, że jest to logiczne jedynie przy założeniu negatywnych konotacji. Jeśli zdanie: „odpowiedzialność ciąży na sprawcy" opisać słowami neutralnymi, to okaże się, że wyrażenie „osoba jest odpowiedzialna za swoje działania” konotuje obrazy znacznie bardziej pozytywne, choć w swej wymowie nieco purytańskie. Natomiast gdyby nacechować tę konstatację pozytywnie i powiedzieć: „osoba jest odpowiedzialna za swoje dokonania”, wówczas konotujące obrazy mogą ukazać odbiór jakiejś nagrody, społeczne uznanie itp. Ingarden skupił się jednak na negatywnej stronie odpowiedzialności. Wyszedł z założenia, że stało się coś złego, tj. wartości zostały pogwałcone lub niezrealizowane. Dopuszczał oczywiście odpowiedzialność za czyn realizujący wartości pozytywne, ale wspominał o tym marginalnie, w drugiej kolejności i w słowach neutralnie konotujących ${ }^{32}$.

Należy również zwrócić uwagę na podejście Ingardena do powinności wynikających z odpowiedzialności. Postulował on, że wszelkie działania, którym przypisana jest odpowiedzialność, nakładają na czyniącego pewne powinności. Jeśli był to czyn moralnie zły, wówczas na osobę odpowiedzialną nałożona jest powinność odpokutowania czy zadośćuczynienia. Jeśli tego nie uczyni, to obciąży się nową winą. Z drugiej strony jeśli czyn jest moralnie dobry, to osoba ma prawo - ale nie obowiązek - do żądania uznania. Wówczas wobec ludzi świadomych zasługi danej osoby powstaje powinność wynagrodzenia lub uznania sprawcy. Jeśli powinność nie zostanie spełniona, wówczas nałożona zostanie powinność odpokutowania lub zadośćuczynienia za zaniechanie własnej powinności.

${ }^{31}$ R. Ingarden, O odpowiedzialności..., s. 75.

${ }^{32}$ Zob. R. Ingarden, O odpowiedzialności..., s. 93, pkt 1, 2. 
Wszystko to jednak opiera się na fundamencie aksjologicznym w przedstawionej powyżej wersji. Można zatem przyjąć, że ustalając jako podstawę ontyczną odpowiedzialności aksjologię, Ingarden na powrót zamknął ją w obrębie odpowiedzialności moralnej, co stoi w niejakiej sprzeczności z założeniami przyświecającymi mu na początku omawianego tekstu.

4. KRYTYKA KONCEPCJI ODPOWIEDZIALNOŚCI INGARDENA I JEJ UZUPEŁNIENIE ODNOŚNIE DO PUNKTU 1: „KTOŚ PONOSI ODPOWIEDZIALNOŚĆ ZA COŚ ALBO INACZEJ MÓWIĄC, JEST ZA COŚ ODPOWIEDZIALNY"33

Założenie Ingardena, że odpowiedzialny może być tylko ten człowiek, który w momencie działania jest świadomy swojego czynu, wartości przez niego realizowanych lub pogwałcanych i znajduje się w „normalnym” stanie psychicznym, wynika z założeń, które trudno utrzymać. Przede wszystkim, na co wskazał sam autor Książeczki o człowieku, w zasadzie nie sposób jednoznacznie ustalić granicy wystarczającego stanu uświadomienia, w związku z którym można już mówić o odpowiedzialności. Tego rodzaju podział wydaje się arbitralny i miesza płaszczyzny analizy, tj. obiektywnie istniejący związek podmiotu z jego czynem oraz płaszczyznę odpowiedzialności moralnej. Jeżeli przyjąć założenie, że tylko osoby spełniające wymienione przez Ingardena kryteria są odpowiedzialne za swoje czyny, to okazałoby się, że za dużą część zbrodni nie jest odpowiedzialny nikt, gdyż w drugim człowieku, np. o innym kolorze skóry, nie widziano osoby jako wartości bezwzględnej, a jedynie mówiące narzędzie lub nieposłuszne zwierzę, a zatem nie można byłoby mówić o dostatecznym stanie uświadomienia sobie czynionego zła. Również wszelkie czyny dzieci znajdowałyby się poza obszarem odpowiedzialności, a wówczas trudno byłoby uzasadnić, na jakiej podstawie przebiega proces socjalizacji i nauki. Dziecko, uderzając kolegę, działa

${ }^{33}$ R. Ingarden, O odpowiedzialności..., s. 73-74. 
afektywnie, tj. nie rozpoznaje wartości, nie jest świadome swojego czynu i bazuje na odruchach, a mimo to nie powiemy, że za dany czyn nie jest odpowiedzialne, co też rodzice dzieciom tłumaczą - i jak się okazuje, przynosi to pożądane efekty. Przykłady można mnożyć. Wróćmy jednak do samych założeń Ingardena.

Aby zrozumieć omawiane pomieszanie płaszczyzn analizy, konieczne jest dostrzeżenie, że czyn wedle autora Książeczki o człowieku pozostaje w obiektywnej relacji odpowiedzialności z osobą, jeżeli odnosi się on do jakichkolwiek wartości. Zostało już wykazane, że implikuje to założenie o obiektywnym i hierarchicznie istniejącym świecie wartości. Nie ulegając w żadnej mierze relatywizmowi moralnemu, trudno nie zauważyć - zwłaszcza po zapoznaniu się z alternatywnymi kulturowo modelami moralności - że założenie o istnieniu obiektywnego świata wartości i ich niezmiennej lub niemal niezmiennej hierarchii nie znajduje podstaw w obserwacji świata. Podkreślam, że nie jest to pochwała stanowisk relatywnych, ale rozwinięcie tematu byłoby zbyt obszerne, aby włączać je w formie dygresji do prowadzonych rozważań. Ważna jest $\mathrm{w}$ tym momencie jedynie negacja istnienia rozumianego obiektywnie i hierarchicznie świata wartości, z uwagi na brak dowodów czy przesłanek ${ }^{34}$. Wobec tego konieczne jest tymczasowe zawieszenie sądów o wartościach i skupienie się na samej odpowiedzialności. Jeśli bowiem założymy, że jedynie za czyny nieobojętne wobec obiektywnych wartości można ponosić odpowiedzialność, wówczas możemy mówić

${ }^{34}$ Nie chcę negować dokonań Hartmanna, Maxa Schelera czy Dietricha von Hildebranda, niemniej uznanie (w różnych formach), że człowiek odpowiednio wrażliwy na wartości potrafi je rozpoznać oraz dać im właściwą odpowiedź, nie wytrzymuje analizy porównawczej z przedstawicielami odmiennych kultur niż euroatlantycka. Przykładem może być niezrozumienie kategorii osoby w systemach etycznych Dalekiego czy Bliskiego Wschodu. Por. np. B. Koehler, Pojęcie osoby w buddyzmie, w: Archeus. Studia z bioetyki $i$ antropologii filozoficznej, red. M. Nowacka, t. 5, Białystok 2004, s. 103-111; E. Wnuk-Lisowska, Islam: między herezja a ortodoksją, Kraków 2013, s. 87-102; B. Warner, Szariat dla niemuzułmanów, tłum. zbiorowe (Centrum Myśli nad Politycznym Islamem), Brno 2016, s. 2onn. 
jedynie o odpowiedzialności moralnej ${ }^{35}$. Chciałbym jednak zaproponować inne rozumienie odpowiedzialności, bardziej fundamentalne niż Ingardenowskie, które nie podważa jego rozważań, ale wychodzi poza obszar odpowiedzialności moralnej i nie wiąże się z wartościami. Tym samym podążam za tezą autora Książeczki o człowieku, że „odpowiedzialność moralna stanowi tylko pewien szczególny wypadek”36 odpowiedzialności.

Przede wszystkim konieczne jest konsekwentne i jasne rozdzielenie tych sfer odpowiedzialności, które na początku swojego tekstu wyróżnił Ingarden:

1. Ktoś ponosi odpowiedzialność za coś albo inaczej mówiąc, jest za coś odpowiedzialny. 2. Ktoś podejmuje odpowiedzialność za coś. 3. Ktoś jest za coś pociągany do odpowiedzialności. 4. Ktoś działa odpowiedzialnie ${ }^{37}$.

Nie chcę głębiej wchodzić w punkty 2-4. Ważne jest jedynie, że nie mogą one zaciemniać analizy punktu 1 przez bycie z nim mylonymi ${ }^{38}$.

Rozdzielenie obiektywnej odpowiedzialności za dany czyn z ponoszeniem odpowiedzialności pozwala zauważyć, że znika konieczność uszczegółowienia przypadłości osób, które mogą być odpowiedzialne. Przypadłości te, wskazane przez Ingardena, są niezwykle istotne przy orzekaniu czyjejś winy lub niewinności - rozpatrując zagadnienie przez pryzmat punktu 3, czyli pociągania do odpowiedzialności. Odłączenie się natomiast od konieczności rozpatrywania odpowiedzialności jedynie w kontekście czynów nieobojętnych moralnie pozwala na wprowadzenie następujących uzupełnień w teorii Ingardena. Przede wszystkim

${ }^{35}$ Nawet przy założeniu, że wartości istnieją tylko relacyjnie i są tworem ludzkim, włączanie ich do refleksji o odpowiedzialności ontycznej sytuuje nas za każdym razem w obszarze odpowiedzialności moralnej.

${ }^{36}$ R. Ingarden, O odpowiedzialności..., s. 73.

${ }^{37}$ R. Ingarden, O odpowiedzialności..., s. 73-74.

${ }^{38}$ Ingarden silnie łączył punkt 1 i 3. W mniejszym zaś stopniu do analizy punktu 1 włączał analizę punktu 2. 
każdy czyn wykonany przez daną osobę jest z nią związany w kategoriach odpowiedzialności - obojętne jest, czy była ona czegoś świadoma, czy nie. Jeśli to świadomość i wiedza stanowiłyby o odpowiedzialności w tym najbardziej pierwotnym sensie, to wówczas należałoby mówić o relacji łączącej czyn ze świadomością, a nie z osobą ${ }^{39}$. Nie jest jednak możliwe mówienie o świadomości bez osoby, możliwe zaś jest mówienie o osobie bez świadomości, co ukazuje obiektywną hierarchię ontologiczną obu bytów. Zatem odpowiedzialność w sensie najbardziej fundamentalnym jawi się jako obiektywnie istniejący związek pomiędzy osobą a jej czynem. Abstrahując od kwestii, czy istnieją czyny neutralne aksjologicznie, istotne jest wskazanie, że tego rodzaju odpowiedzialność nie prowadzi do oceny czynu lub osoby, a jedynie do określenia istniejącej relacji między danym czynem a osobą czyniącą. Charakter tej relacji jest obiektywny, gdyż nie ma czynu bez jego „sprawcy”. Można jej oczywiście nie uznać, co jest kolejną relacją odpowiedzialności, tzn. jestem odpowiedzialny za nieuznanie istnienia obiektywnej relacji, którą sam się związałem.

W tym punkcie rozważań ważne jest zastanowienie się nad wolną wolą i wolnymi działaniami, tj. wolnymi aktami „ja osobowego” (mówiąc językiem Ingardena), oraz determinizmem. Autor $O$ dziele literackim uznawał, że człowiek jest układem względnie izolowanym i absolutna wolność ja osobowego oraz zupełny determinizm zewnętrzny są biegunami, między którymi rozpięta jest osoba - o czym już pisałem. Znów jednak wydaje się, że uwzględnianie czynników determinujących zachowanie wynika z rozumienia odpowiedzialności na płaszczyźnie moralnej. Osoba zmuszona do zrobienia czegoś oczywiście nie może być oceniana tak samo, jak ktoś, kto zrobił to samo, ale „z własnej woli”. Niemniej

${ }^{39} \mathrm{~W}$ przeciwnym razie wynikałaby następująca konstatacja: osoba = świadomość, co znajduje wielu zwolenników, ale jak dotąd nie zostało poparte należytymi dowodami. Por. np. prace Johna Locke’a, Petera Singera, Dereka Parfita czy Davida Hume'a: J. Locke, Rozważania dotyczace rozumu ludzkiego, t. I, tłum. B. J. Gawecki, Warszawa 1955, s. 460-493; P. Singer, Etyka praktyczna, tłum. A. Sagan, Warszawa 2003, s. 170nn.; D. Parfit, Reasons and Persons, Oxford 1984; D. Hume, Traktat o naturze ludzkiej, tłum. C. Znamierowski, Warszawa 1963, s. 325-341. 
trudno uważać, że działanie pod przymusem, choćby najsurowszym, jest pozbawione osoby za nie - w najbardziej fundamentalnym sensie odpowiedzialnej. Moralnie może być za nie odpowiedzialny ktoś inny, ale jest to już kwestia, którą można rozpatrywać dopiero w punkcie 3 zaproponowanego przez Ingardena podziału.

Konieczne jest zastanowienie się nad wolitywnością aktu. Kwestię tę podniósł w rozmowie ze mną Adam Workowski, któremu dziękuję za uwagi. Jeśli chcemy bowiem wykazać obiektywne istnienie odpowiedzialności, wówczas musimy założyć, że człowiek działa jako podmiot wolny. Gdyby był zniewolony, wtedy odpowiedzialność przeniosłaby się na tego, kto go zniewolił; wspominał o tym również Ingarden. Wydaje się jednak, że absolutny determinizm czynu nie istnieje - przynajmniej jak dotąd go nie wykazano. Zawsze zatem jest możliwość wyboru czynu. Założywszy jednak, że osoba może być zdeterminowana w stopniu absolutnym, nie możemy przyjmować, że tylko ona jest zdeterminowana. Jeśli osobę zdeterminowaną oznaczymy $\mathrm{B}$, a osobę, która zniewoliła w stopniu absolutnym wolę B, oznaczymy A, to nie istnieją racjonalne przesłanki, aby uznać, że tylko B jest zdeterminowana w stopniu absolutnym. Być może A również jest zdeterminowana w stopniu absolutnym - i wszyscy na świecie tak samo. Taką możliwość trzeba uwzględnić, jeśli przyjmie się, że przynajmniej jedna osoba może być absolutnie zdeterminowana. Jeśli zaś nie możemy tego odrzucić, to musimy przyjąć albo przyczynowo-skutkową definicję odpowiedzialności, którą obrazowałyby w pewnym sensie relacje mechaniczne, albo uznać, że nikt nie jest odpowiedzialny. Oba wnioski i ich spekulatywnie przyjęte przesłanki nie odpowiadają elementarnemu, a także pogłębionemu doświadczeniu i oglądowi rzeczywistości. Dużo bardziej przemyślana i odpowiadająca powszechnym postrzeżeniom jest teza Ingardena o układzie względnie izolowanym, który nigdy nie przyjmując jednej z pozycji granicznych, zawsze pozostaje w możności dokonania wolnego aktu, więc zawsze można mu przypisać odpowiedzialność fundamentalną.

W świetle powyższej argumentacji konieczne jest odniesienie się również do wyników działań osoby. Ingarden twierdził, że jeżeli zachodzą wszystkie czynniki umożliwiające orzekanie o odpowiedzialności, 
wówczas osoba jest również odpowiedzialna za skutki swoich działań. Poza jednym wyjątkiem zgadzam się z tezą Ingardena - pamiętając o rozszerzonym rozumieniu fundamentalnej odpowiedzialności. Ów wyjątek stanowi oddziaływanie na inne osoby. Otóż niejednokrotnie można spotkać się z twierdzeniem, że działanie osoby A wpłynęło na działanie osoby B i dlatego tylko osoba A miałaby być odpowiedzialna lub przynajmniej „bardziej odpowiedzialna” - do stopniowalności odpowiedzialności zaraz dojdziemy. Gdyby rzeczywiście odpowiedzialność mogła dotyczyć tylko osoby A, wówczas oznaczałoby to degradację osoby B do bezwolnego układu wykonującego wolę innej osoby, czyli osoba B byłaby narzędziem. Pomijając praktykę języka codziennego - „ktoś jest czyimś narzędziem” / „ktoś się kimś posłużył” - nie ma racjonalnych podstaw, aby twierdzić, że mimo iż osoba B coś zrobiła z uwagi na działanie osoby A, to nie jest odpowiedzialna, w rozumieniu fundamentalnym, za swój czyn. Czy zatem za ów czyn byłaby odpowiedzialna osoba $\mathrm{A}$ ? Tu również nie ma racjonalnych podstaw, aby uważać, że jest się odpowiedzialnym za cudze czyny.

Pojawia się jednak kwestia odpowiedzialności za idee. Powiedzmy, że osoba A napisała tekst, w którym wyłożyła swoją autorską tezę. Jest za to odpowiedzialna - zarówno za napisanie książki, jak też za samą ideę. Osoba B po przeczytaniu tekstu przejęła ideę osoby A. Pod wpływem idei i tekstu osoby A osoba B coś przedsięwzięła. Oznaczmy samo przedsięwzięcie jako $x$, a jego skutek jako $y$. Kto jest więc odpowiedzialny za $x$ i $y$ ? Na płaszczyźnie fundamentalnej jedynie osoba B. Nie jest ona jednak odpowiedzialna za ideę, ale za jej realizację i wynikające z tego czynu skutki. Być może na gruncie odpowiedzialności moralnej okazałoby się, że odpowiedzialność rozkłada się inaczej. Jednak na płaszczyźnie odpowiedzialności fundamentalnej nie ma racjonalnych podstaw, aby uważać, że za $x$ i $y$ odpowiedzialna jest osoba A. W tym kontekście Ingarden rozważał kwestię współodpowiedzialności ${ }^{40}$.

Współodpowiedzialność czy odpowiedzialność zbiorowa są to koncepcje, dla których nie znaleziono jak dotąd logicznego uzasadnienia.

${ }^{40}$ Zob. R. Ingarden, O odpowiedzialności..., s. 87-88. 
Mówiąc najprościej, nie ma koniecznego związku pomiędzy działaniem osoby A i działaniem osoby B - jak też nie ma racjonalnych przesłanek, by taki związek uznawać. Oczywiście działania te mogą być skorelowane, tj. osoba B podejmuje jakieś działanie z uwagi na działania osoby A - jak ma to miejsce np. podczas licytacji giełdowych - ale nie ma w tych działaniach zdeterminowania. Podobnie: gdy pewna grupa osób podejmuje się wspólnego dzieła, wówczas mówi się, że grupa lub lider są za coś odpowiedzialni. Na gruncie „rozliczeń” społecznych rzecz jasna uznaje się dla wygody tego rodzaju model. Niemniej jest on konwencjonalny i nie wynika z konieczności. W działaniach grupowych za sukces lub porażkę nie jest odpowiedzialny każdy z osobna. Sukces lub porażka są sumą indywidualnych działań, za które każdy podmiot ponosi indywidualną odpowiedzialność w jej wymiarze fundamentalnym, co nie oznacza, że w przestrzeni społecznej nie upraszcza się rozumienia sukcesu i porażki do odpowiedzialności zbiorowej czy współodpowiedzialności - co znajduje wyraz w języku potocznym. Dla niniejszych rozważań nie są to jednak płaszczyzny interesujące i właściwe.

Ostatnim elementem, o który chciałbym uzupełnić omawiany punkt koncepcji Ingardena, jest problem stopniowalności odpowiedzialności. Polski fenomenolog twierdził w analizie punktu 1, że:

\section{(...) odpowiedzialność (...) może być mianowicie również albo bezwa- runkowa i zupełna, albo w rozmaity sposób uwarunkowana i ograni- czona czy podzielona odpowiednio do różnych możliwych sposobów, zgodnie z którymi pewna decyzja bądź działanie jest „własnym” czynem człowieka $^{41}$.}

Tego rodzaju tezę można utrzymać na gruncie odpowiedzialności moralnej przy założeniu, że istnieje „waga” wartości, o czym już była mowa. Jednak w wymiarze fundamentalnym odpowiedzialności, tzn. bycia odpowiedzialnym za coś, wszelka odpowiedzialność jest równa, gdyż jest to relacja łącząca osobę z jej działaniem, która nie podlega okre-

${ }^{41}$ R. Ingarden, O odpowiedzialności..., s. 86. 
śleniom wartościującym. Nie ma podstaw, aby twierdzić, że skoro działałem pod wpływem alkoholu, to moja odpowiedzialność za czyn $x$ jest mniejsza, niż gdybym był trzeźwy - lub odwrotnie. Odpowiedzialność w swym wymiarze fundamentalnym jest niemierzalna, więc nie można określić, że odpowiedzialność osoby A jest większa niż osoby B. Działa tu zasada wykluczonego środka - albo odpowiedzialność jest, albo jej nie ma. Oczywiście na gruncie języka używanego w codziennych rozmowach utarło się stopniować odpowiedzialność, przenosić ją lub z niej zwalniać ${ }^{42}$. Jest to jednak kwestia istotna dla językoznawców lub socjologów.

Podsumujmy uzupełnienia punktu 1 koncepcji Ingardena. Przede wszystkim w analizie odpowiedzialności na jej najbardziej fundamentalnym poziomie konieczne jest, aby precyzyjnie odłączyć ją od kategorii aksjologicznych i powinnościowych, które wynikają z założeń aksjologicznych. To pozwala na usunięcie postulowanego przez autora Książeczki o człowieku podziału na osoby, które mogą być odpowiedzialne, i osoby „pozaodpowiedzialne”. Brak odniesień aksjologicznych oraz zrozumienie ontycznego i obiektywnego charakteru odpowiedzialności na poziomie fundamentalnym, tj. jako relacji łączącej osobę z jej działaniami, pozwala odrzucić tezę o stopniowalności odpowiedzialności. To samo dotyczy odrzucenia odpowiedzialności zbiorowej lub współodpowiedzialności, za którymi to koncepcjami nie przemawiają żadne racjonalne przesłanki.

Tak uzupełniona myśl Ingardena pozwala na prowadzenie analizy odpowiedzialności w duchu postulowanym przez jej pomysłodawcę, czyli w oparciu o jej ontyczne - a zatem konieczne i wystarczające dla jej zaistnienia - podstawy. Stąd też można ów poziom analizy, który u autora Książeczki o człowieku stanowił poziom pierwszy, nazwać poziomem odpowiedzialności fundamentalnej. Reszta refleksji polskiego

42 Przykładowo: „Pani sąsiad strasznie pije i potem się awanturuje! Ale to jego żona jest za to najbardziej odpowiedzialna, bo od lat przyprawia mu rogi”. Tego rodzaju potoczne używanie słowa „odpowiedzialność” jest niewystarczające do analizy filozoficznej, zwłaszcza jeżeli chodzi o odpowiedzialność fundamentalną. 
fenomenologa, przy zastosowaniu wskazanych uzupełnień i ścisłym rozdzieleniu poziomów odpowiedzialności, wydaje się płodną i wartościową odpowiedzią na szerzący się we współczesnej filozofii - i nie tylko - relatywizm moralny lub tzw. pluralizm wartości.

\section{CRITICISM RECOGNIZED BY ROMAN INGARDEN ONTIC BASES RESPONSIBILITY}

\section{SUMMARY}

The goal of this paper is to identify deficiencies of Roman Ingarden's concept of responsibility. It points to a couple of illegitimate assumptions made by Ingarden. Moreover, in the place of rejected elements of his analyses, it proposes supplements coherent to Ingarden's further line of thought. One of these proposed supplements is an attempt to introduce a category of "fundamental responsibility" which is ontically fundamental.

\section{KEYWORDS}

ontology, responsibility, ethics, fundamental responsibility, Roman Ingarden

BIBLIOGRAFIA

Hartmann N., Ethik, Berlin 1962.

Hume D., Traktat o naturze ludzkiej, ttum. C. Znamierowski, Warszawa 1963. Ingarden R., O odpowiedzialności i jej podstawach ontycznych, tłum. A. Węgrzecki, w: R. Ingarden, Książeczka o człowieku, Kraków 2003.

Ingarden R., Spór o istnienie świata, t. I, tłum. D. Gierulanka, Warszawa 1987. Koehler B., Pojęcie osoby w buddyzmie, w: Archeus. Studia z bioetyki i antropologii filozoficznej, red. M. Nowacka, t. 5, Białystok 2004.

Locke J., Rozważania dotyczace rozumu ludzkiego, t. I, tłum. B. J. Gawecki, Warszawa 1955.

Parfit D., Reasons and Persons, Oxford 1984. 
Singer P., Etyka praktyczna, tłum. A. Sagan, Warszawa 2003.

Warner B., Szariat dla niemuzułmanów, tłum. zbiorowe (Centrum Studiów nad Politycznym Islamem), Brno 2016.

Wnuk-Lisowska E., Islam: między herezją a ortodoksją, Kraków 2013. 